\title{
Effect of water stress at different periods on seed yield and water use efficiency of guar under Shambat conditions
}

\author{
Mahmoud Fadl El Mula Ahmed*, Deng Manasseh Mac, Awatif Abdel Gadir Bashir
}

Faculty of Agriculture, University of Khartoum, Shambat, Sudan; ${ }^{*}$ Corresponding Author: mfahmed@yahoo.com

Received 13 January 2011; revised 21 April 2011; accepted 2 July 2011.

\begin{abstract}
Water stress effects on seed yield and water use efficiency of three indeterminate guar (Cyamopsis tetragonoloba $\mathrm{L}$. Taub.) lines $\left(\mathrm{L}_{12}, \mathrm{~L}_{18}\right.$ and $L_{33}$ ) were investigated in the experimental farm of the Faculty of Agriculture, University of Khartoum for two seasons (2005 and 2006). The guar lines were subjected to water stress induced by withholding irrigation for three weeks. Three water stress treatments were imposed 35, 50 and 65 days after sowing (DAS), and a control treatment irrigated every two weeks. The treatments were arranged in a split-plot design with three replications; with water regime treatments assigned to the main plots and guar lines to the sub-plots. Data were recorded on seed yield $\left(\mathrm{t} \cdot \mathrm{ha}^{-1}\right)$, number of pods per plant, 1000seed weight $(\mathrm{g})$, harvest index $(\mathrm{HI})$ and water use efficiency at harvest.

The results indicated that exposure of several cultivars of guar to water stress at the three stages of growth didn't induce any significant effect on number of pods per plant, 1000-seed weight, seed yield and water use efficiency (WUE). On the other hand there was significant reduction in harvest index as a result of imposition of water stress at $\mathbf{3 5}$ and 50 DAS. It was also evident that plants re-watered after the stress recovered and had the same values as the control treatment.
\end{abstract}

Keywords: Guar; Water Stress; Water Use Efficiency; Harvest Index

\section{INTRODUCTION}

Guar [Cyamopsis tetragonoloba (L.) Taub.] grains are a source of guar gum which has many uses in food, paper manufacturing, textile printing, and pharmaceutical industries. Nevertheless, the best known use is as a friction-reducing additive in drilling mud in petroleum oil production [1].

The bulk production of guar is in the arid and semiarid zones of India, Pakistan, USA, Australia and Africa, where rainfall is the most important yield and growth determining environmental factor. Guar is generally considered as a drought tolerant crop; few studies have shown that water stress experienced during critical growth stages can lead to substantial reduction of seed yield. Boutraa and Sanders in 2001 [2] reported that water stress during both flowering and pod-filling stages decreased seed yield. It was also found that moisture stress at flowering stages was more detrimental for obtaining higher pod yield [3].

Crop water use efficiency (WUE) is defined as the ratio of seed yield to water used (consumptive use of water). However, it was observed that WUE might not provide much information about the competitive or yield advantage of one particular species over another because improved WUE may actually restrict growth with relatively small increments in yield and still WUE, as a ratio, is improved [4]. Crop yield was defined by [5] for water limited environment as: "water transpired, while increase in WUE, and harvest index" may result in increase in yield, although these three values are independent of each other.

Several studies have reported considerable variation in WUE among crop plants. However, under optimum water management practices [1] reported that water use efficiencies expected for guar crop ranged from about 0.40 to $0.60 \mathrm{~kg} \cdot \mathrm{m}^{-3}$.

In the Sudan, although guar production is gaining ground, there is very little information on its efficiency of water use under drought conditions. However, it is worth noting that, under biological studies, experimental results are always location and environment dependent. Thus, there is a need for more studies to identify stages at which cultivars are more tolerant to water stress and those ones which are more efficient in their water use. 
The aim of this study, therefore, was to investigate the effect of water stress on seed yield and WUE of irrigated guar under Shambat conditions.

\section{MATERIALS AND METHODS}

A field trial was conducted under irrigation for two consecutive seasons (2005 and 2006), at the experimental farm of the Faculty of Agriculture, University of Khartoum, Shambat, Sudan, Located at latitude $\left(15^{\circ} 40^{\prime}\right)$ $\mathrm{N}$, Longitude $\left(32^{\circ} 32^{\prime}\right) \mathrm{E}$, and altitude $380 \mathrm{~m}$ above sea level. Land was prepared by disc ploughing, harrowing, leveling and ridging.

The experimental material consisted of three indeterminate guar lines coded $\mathrm{L}_{12}, \mathrm{~L}_{18}$, and $\mathrm{L}_{33}$ and four water regimes namely, $\mathrm{WS}_{1}$ (stressed at $35 \mathrm{DAS}$ ), $\mathrm{WS}_{2}$ (stressed at $50 \mathrm{DAS}$ ), and $\mathrm{WS}_{3}$ (stressed at $65 \mathrm{DAS}$ ) and the (control treatment $\mathrm{WS}_{0 \text { ) }}$ which was never stressed and irrigated every two weeks. Water stress was imposed at a particular period, by withholding irrigation for three weeks and then irrigated as in control $\left(\mathrm{WS}_{0}\right)$.

The trial was laid out in a split plot design replicated three times with plot size of $12 \mathrm{~m}^{2}$. Water regime treatments were assigned to main plots, and guar lines were assigned to the subplots. Sowing was on the third of July in both seasons, at a spacing of $0.70 \mathrm{~m}$ between rows and $0.40 \mathrm{~m}$ between plants within rows.

The crop was kept weed free by hand weeding at 21 and 33 DAS in the two seasons and no pests or diseases were observed in both seasons.

In both seasons records were taken for the number of pods per plant, 1000-seed weight, grain yield harvest index and crop water use efficiency (WUE). The evaluation of water use efficiency (WUE) was based on the relation between consumptive use (CU), and seed yield for each water regime treatment in both seasons.

Harvesting was on Nov. 2, 2005 (121 DAS) in the first season, and Oct. 28, 2006 (119 DAS) in the second season.

Analysis of variance was based on the general linear model procedures of the Statistical Analysis System (SAS). The least significant difference (LSD) at 0.05 level of probability was used to detect means differences between treatment means

\section{RESULTS AND DISCUSSION}

\subsection{Number of Pods per Plant}

There were no significant differences in the number of pods per plant under the water regime treatments in both seasons, (Table 1). However, treatment WS2 (withholding irrigation at 50 DAS) showed a tendency to reduce average number of pods per plant compared to the rest of treatments in both seasons. Several workers reported that water stress caused more shedding of flowers, immature pods and smaller seeds, e.g. [2]. However, in this experiment, stressed plants at 65 DAS did not show this response. Increased amounts of irrigation water or sampling errors are possible reasons for this clear discrepancy. Moreover, [6] reported that pod density was most affected by water stress, among yield components with pod reduction averaging more than $50 \%$, mainly due to the reduced flower production and the greater abortion of flowers.

Line $\mathrm{L}_{12}$ produced more pods per plant compared with the other two lines $\left(\mathrm{L}_{18}\right.$ and $\left.\mathrm{L}_{33}\right)$ which were not significantly different. This result may suggest that lines L18 and $\mathrm{L}_{33}$ were more susceptible to water stress than line $\mathrm{L}_{12}$.

\subsection{0-Seed Weight (g)}

On average, the weight of 1000 seeds was not significantly affected by the different water regimes in both seasons (Table 2). This result is in line with that of [7] who found no effect of drought on mean faba bean seed weight. There was no effect of the treatments on seed weight as was reported by [8] in their experiment, which indicates that the seed size was not affected by the stress. On the other hand, the present result is in disagreement with the finding of [9] who reported a decrease of about $34 \%$ in the mean seed weight of the stressed faba bean plants, compared to the fully irrigated treatment. Reduc-

Table 1. Average number of pods per plant as affected by water stress and guar lines during the two seasons (2005 and 2006).

\begin{tabular}{|c|c|c|c|c|c|c|c|c|c|c|}
\hline \multirow{3}{*}{ Treatment } & \multicolumn{5}{|c|}{ Season (2005) } & \multicolumn{5}{|c|}{ Season (2006) } \\
\hline & \multicolumn{5}{|c|}{ Lines } & \multicolumn{5}{|c|}{ Lines } \\
\hline & $\mathrm{L}_{12}$ & $\mathrm{~L}_{18}$ & $\mathrm{~L}_{33}$ & Mean & LSD (0.05) & $\mathrm{L}_{12}$ & $\mathrm{~L}_{18}$ & $\mathrm{~L}_{33}$ & Mean & LSD (0.05) \\
\hline $\mathrm{WS}_{0}$ & 147.9 & 108.9 & 130.7 & $129.1^{\mathrm{A}}$ & & 142.2 & 82.6 & 74.1 & $99.7^{\mathrm{A}}$ & \\
\hline $\mathrm{WS}_{2}$ & 114.6 & 100.6 & 156.6 & $123.9^{\mathrm{A}}$ & n.s & 76.9 & 74.2 & 109.3 & $86.8^{\mathrm{A}}$ & n.s \\
\hline $\mathrm{WS}_{3}$ & 173.2 & 118.3 & 120.8 & $137.4^{\mathrm{A}}$ & & 107.2 & 92.9 & 63.7 & $87.9^{\mathrm{A}}$ & \\
\hline Mean & $158.2^{\mathrm{a}}$ & $102.8^{\mathrm{b}}$ & $142.4^{\mathrm{ab}}$ & & & $114.3^{\mathrm{a}}$ & $87.5^{\mathrm{a}}$ & $74.2^{\mathrm{a}}$ & & \\
\hline $\operatorname{LSD}(0.05)$ & & 44.94 & & & & & n.s & & & \\
\hline
\end{tabular}

Means with the same letter(s) in a column or a row are not significantly different at LSD $=0.05$; $\mathrm{WS}_{0}=$ control treatment (irrigated every two weeks), WS $1=$ stressed at 35 days after sowing, $\mathrm{WS}_{2}=$ stressed at $50 \mathrm{DAS}$ and $\mathrm{WS}_{3}=$ stressed at 65 DAS. 
Table 2. Average 1000-seed weight (g) as affected by water stress and guar lines during the two seasons (2005 and 2006).

\begin{tabular}{|c|c|c|c|c|c|c|c|c|c|c|}
\hline \multirow{3}{*}{ Treatment } & \multicolumn{5}{|c|}{ Season (2005) } & \multicolumn{5}{|c|}{ Season (2006) } \\
\hline & \multicolumn{5}{|c|}{ Lines } & \multicolumn{5}{|c|}{ Lines } \\
\hline & $\mathrm{L}_{12}$ & $\mathrm{~L}_{18}$ & $\mathrm{~L}_{33}$ & Mean & LSD (0.05) & $\mathrm{L}_{12}$ & $\mathrm{~L}_{18}$ & $\mathrm{~L}_{33}$ & Mean & $\operatorname{LSD}(0.05)$ \\
\hline $\mathrm{WS}_{0}$ & 30.0 & 30.6 & 31.3 & $30.6^{\mathrm{A}}$ & & 32.0 & 33.0 & 33.8 & $32.9^{\mathrm{A}}$ & \\
\hline $\mathrm{WS}_{2}$ & 30.3 & 30.6 & 34.0 & $31.6^{\mathrm{A}}$ & n.s & 29.7 & 31.0 & 34.6 & $31.7^{\mathrm{A}}$ & n.s \\
\hline $\mathrm{WS}_{3}$ & 29.0 & 31.3 & 31.2 & $30.5^{\mathrm{A}}$ & & 31.6 & 31.6 & 33.2 & $32.1^{\mathrm{A}}$ & \\
\hline Mean & $30.1^{\mathrm{b}}$ & $31.0^{\mathrm{b}}$ & $33.0^{\mathrm{a}}$ & & & $31.4^{b}$ & $31.7^{\mathrm{b}}$ & $33.3^{\mathrm{a}}$ & & \\
\hline LSD $(0.05)$ & & 1.95 & & & & & 1.30 & & & \\
\hline
\end{tabular}

Means with the same letter(s) in a column or a row are not significantly different at LSD $=0.05$; Legends are as in Table.

Table 3. Average seed yield $\left(\mathrm{t} \cdot \mathrm{ha}^{-1}\right)$ as affected by water stress and guar lines during the two seasons (2005 and 2006).

\begin{tabular}{|c|c|c|c|c|c|c|c|c|c|c|}
\hline \multirow{3}{*}{ Treatment } & \multicolumn{5}{|c|}{ Season (2005) } & \multicolumn{5}{|c|}{ Season (2006) } \\
\hline & \multicolumn{5}{|c|}{ Lines } & \multicolumn{5}{|c|}{ Lines } \\
\hline & $\mathrm{L}_{12}$ & $\mathrm{~L}_{18}$ & $\mathrm{~L}_{33}$ & Mean & LSD (0.0) & $\mathrm{L}_{12}$ & $\mathrm{~L}_{18}$ & $\mathrm{~L}_{33}$ & Mean & LSD (0.05) \\
\hline $\mathrm{WS}_{0}$ & 2.6 & 1.8 & 1.6 & $2.0^{\mathrm{A}}$ & \multirow{5}{*}{ n.s } & 2.1 & 1.3 & 1.2 & $1.5^{\mathrm{A}}$ & \multirow{5}{*}{ n.s } \\
\hline $\mathrm{WS}_{2}$ & 2.0 & 1.5 & 2.8 & $2.1^{\mathrm{A}}$ & & 1.3 & 1.2 & 1.6 & $1.4^{\mathrm{A}}$ & \\
\hline $\mathrm{WS}_{3}$ & 2.2 & 1.2 & 1.8 & $1.7^{\mathrm{A}}$ & & 2.2 & 1.5 & 1.1 & $1.6^{\mathrm{A}}$ & \\
\hline Mean & $2.4^{\mathrm{a}}$ & $1.4^{\mathrm{b}}$ & $1.8^{\mathrm{ab}}$ & & & $1.8^{\mathrm{a}}$ & $1.3^{\mathrm{a}}$ & $1.2^{\mathrm{a}}$ & & \\
\hline $\operatorname{LSD}(0.05)$ & & 0.67 & & & & & n.s & & & \\
\hline
\end{tabular}

Means with the same letter(s) in a column or a row are not significantly different at LSD =0.05; Legends are as in Table $\mathbf{1}$.

tion in seed size was found by earlier workers e.g. [1012]. Although seed weight is a known component of yield, which reflects relationship between source and sink of photosynthate during pod filling stage, and it is where compensation for earlier losses of pods may occur, thus enhancing the final yield [13].The results of the present study are negating this fact, probably because the magnitude of the stress (between the control and the stressed treatments) was not so acute to disrupt or slow down the assimilate supply (translocation process) to the pods of the stressed plants.

The three guar lines were significantly different in 1000 seed weight in both seasons. However, higher average weights (33.0 and $33.3 \mathrm{~g}$ ) were recorded for line L33 than the other two lines (L12 and L18). This may be attributed to fewer pods per plant. This explanation is supported by the finding of [14] that attributed greater kernel weight to fewer kernels set due to water stress at flowering and better grain filling in the presence of fewer kernels per ear.

\subsection{Seed Yield}

Seed yield was not significantly affected by different water regimes in both seasons (Table 3). This was due to the fact that the most important components of the yield (number of pods per plant and 1000-seed weight), in this study, were not significantly affected by the water stress imposed at 35 DAS and above. Nevertheless, treatment WS1 (withholding irrigation at 35 DAS) gave the lowest seed yield (1.6 and $1.3 \mathrm{t} \cdot \mathrm{ha}^{-1}$ ) in the first and second seasons, respectively. This was probably due to negative effect of water shortage on the vegetative growth espe- cially plant height and number of main branches per plant (data not shown) which had resulted in low number of pods per plant. Similar findings on sesame were reported by [15] as they reported that yield per plant was significantly and positively correlated with stem height and number of branches.

The insignificant difference in seed yield between $L_{12}$ and $\mathrm{L}_{33}$ was due to the fact that yield in the former line was a function of number of pods per plant, whereas in the latter was a function of seed weight. This trend was observed in the second season, but line $\mathrm{L}_{12}$ gave higher seed yield than the other two lines.

Seed yield was greater in the first season than in the second season, due to high number of pods per plant, as a result of high number of branches per plant. Relating this observation to weather conditions (Table 4) during the growing period, it could be concluded that high seed yield was associated with a combination of high water supply (rainfall) and low evaporative demand especially during the early growth stages.

\subsection{Water Use Efficiency (WUE)}

The data presented in Table 5 seem to indicate that stopping irrigation during any one phase of the life cycle of guar plant does not have any significant change on seed yield and eventually on the crop water use efficiency (WUE). This result is in accordance with observation of [7] who found that faba bean water use efficiency was similar among different irrigation treatments since the seed and straw yield linearly depended on total water received. The data also indicated that line $\mathrm{L}_{12}$ is more efficient in its water use than the other two lines 
Table 4. Average harvest index (H.I) of guar as affected by water stress during the two seasons (2005 and 2006).

\begin{tabular}{|c|c|c|c|c|c|c|c|c|c|c|}
\hline \multirow{3}{*}{ Treatment } & \multicolumn{5}{|c|}{ Season (2005) } & \multicolumn{5}{|c|}{ Season (2006) } \\
\hline & \multicolumn{5}{|c|}{ Lines } & \multicolumn{5}{|c|}{ Lines } \\
\hline & $\mathrm{L}_{12}$ & $\mathrm{~L}_{18}$ & $\mathrm{~L}_{33}$ & Mean & LSD (0.05) & $\mathrm{L}_{12}$ & $\mathrm{~L}_{18}$ & $\mathrm{~L}_{33}$ & Mean & $\operatorname{LSD}(0.05)$ \\
\hline $\mathrm{WS}_{0}$ & 39.9 & 30.2 & 28.1 & $32.7^{\mathrm{A}}$ & & 47.1 & 41.9 & 38.0 & $42.3^{\mathrm{A}}$ & \\
\hline $\mathrm{WS}_{2}$ & 32.4 & 33.2 & 40.1 & $35.2^{\mathrm{A}}$ & n.s & 36.4 & 35.8 & 31.0 & $34.4^{\mathrm{A}}$ & n.s \\
\hline $\mathrm{WS}_{3}$ & 40.1 & 22.9 & 25.9 & $29.6^{\mathrm{A}}$ & & 40.4 & 40.9 & 34.7 & $38.7^{\mathrm{A}}$ & \\
\hline Mean & $36.7^{\mathrm{a}}$ & $26.1^{b}$ & $29.3^{\mathrm{b}}$ & & & $43.2^{\mathrm{a}}$ & $40.4^{\mathrm{ab}}$ & $35.3^{\mathrm{b}}$ & & \\
\hline $\operatorname{LSD}(0.05)$ & & 5.47 & & & & & 6.07 & & & \\
\hline
\end{tabular}

Means with the same letter(s) in a column or in a row are not significantly different at LSD =0.05; Legends are as in Table $\mathbf{1}$.

Table 5. Mean water use efficiency (WUE) $\mathrm{kg} \cdot \mathrm{m}^{-3}$ as affected by water stress and guar lines during the two seasons (2005 and 2006 ).

\begin{tabular}{|c|c|c|c|c|c|c|c|c|c|c|}
\hline \multirow{3}{*}{ Treatment } & \multicolumn{5}{|c|}{ Season (2005) } & \multicolumn{5}{|c|}{ Season (2006) } \\
\hline & \multicolumn{5}{|c|}{ Lines } & \multicolumn{5}{|c|}{ Lines } \\
\hline & $\mathrm{L}_{12}$ & $\mathrm{~L}_{18}$ & $\mathrm{~L}_{33}$ & Mean & $\operatorname{LSD}(0.05$ & $\mathrm{L}_{12}$ & $\mathrm{~L}_{18}$ & $\mathrm{~L}_{33}$ & Mean & $\operatorname{LSD}(0.05)$ \\
\hline $\mathrm{WS}_{0}$ & 0.5 & 0.3 & 0.3 & $0.4^{\mathrm{A}}$ & \multirow{5}{*}{ n.s } & 0.4 & 0.2 & 0.2 & $0.3^{\mathrm{A}}$ & \multirow{5}{*}{ n.s } \\
\hline $\mathrm{WS}_{2}$ & 0.4 & 0.3 & 0.6 & $0.4^{\mathrm{A}}$ & & 0.2 & 0.2 & 0.3 & $0.3^{\mathrm{A}}$ & \\
\hline $\mathrm{WS}_{3}$ & 0.4 & 0.2 & 0.4 & $0.3^{\mathrm{A}}$ & & 0.5 & 0.3 & 0.2 & $0.3^{\mathrm{A}}$ & \\
\hline Mean & $0.5^{\mathrm{a}}$ & $0.3^{\mathrm{b}}$ & $0.4^{\mathrm{ab}}$ & & & $0.3^{\mathrm{a}}$ & $0.3^{\mathrm{a}}$ & $0.2^{\mathrm{a}}$ & & \\
\hline LSD $(0.05)$ & & 0.14 & & & & & n.s & & & \\
\hline
\end{tabular}

Means with the same letter(s) in a column or a row are not significantly different at LSD $=0.05$; Legends are as in Table $\mathbf{1}$.

$\left(\mathrm{L}_{18}\right.$ and $\left.\mathrm{L}_{33}\right)$.

\subsection{Harvest Index (HI)}

HI (seed yield as a ratio of the total weight of seeds plus straw) was significantly reduced under treatments $\mathrm{WS}_{1}$ and $\mathrm{WS}_{2}$ as a result of low seed yield (Table 3 ). This result confirms the finding reported by [16], in an experiment at Shambat, attributed the reduction in (HI) of faba beans under water stress during vegetative stage to low seed yield, and attributed the reduction at pod set stage to the effect of drought on the assimilate supply. Moreover, the reduced (HI) under treatment $\mathrm{WS}_{2}$ in the present investigation is in accordance with the findings of [17] who attributed the reduction in (HI) in common bean to the effect of water stress imposed during reproductive stage.

There was genotypic difference among the three lines regarding the harvest index. On average, line $\mathrm{L}_{12}$ gave high harvest indices of 36.7 and 43.2, in the first and second seasons, respectively. This finding indicates that line $\mathrm{L}_{12}$ was high yielding under the conditions of the present investigation. However, the two other lines $\left(\mathrm{L}_{18}\right.$ and $\mathrm{L}_{33}$ ) were not significantly different and can be graded as low seed yielding.

It can be concluded that irrigation treatments did not significantly affect the measured attributes of growth and seed yield. However, the three guar lines showed significant variation, with line $\left(\mathrm{L}_{12}\right)$ being more superior to the other two.

\section{REFERENCES}

[1] Alexander, W.L., Bucks, D.A. and Backhaus, R.A. (1988)
Irrigation water management for guar seed production. Agronomy Journal, 80, 447-453.

doi:10.2134/agronj1988.00021962008000030012x

[2] Boutraa, T. and Sanders, F. E. (2001) Influence of water stress on grain yield and vegetative growth of two cultivars of bean (Phaseolus vulgaris L.). Journal of Agronomy and Crop Science, 187, 251-257.

doi:10.1046/j.1439-037X.2001.00525.x

[3] Reddy, P.S., Babu, K.H. and Reddy, Y.N. (2001) Effect of moisture stress on yield and yield attributes in certain cluster bean cultivars. Orissa Journal of Horticulture, 29, 65-68.

[4] Hubick, K.T, Fraquhar, G.D. and Shorter, R. (1986) Correlation between water use efficiency and carbon isotope discrimination in diverse peanut (Arachis) germplasm. Australian Journal of Plant Physiology, 13, 803-816. doi:10.1071/PP9860803

[5] Passioura, J.B. (1994) The yield of crops in relation to drought. In: Boote, K.J., Bennett, J.M., Sinclair, T.R. and Paulsen, G.M., Eds., Physiology and Determination of Crop Yield, ASA, CSSA and SSSA, Madison, 343-359.

[6] Pandey, R.K., Herera, W.A.T. and Pendleton, J.W. (1984) Drought response of grain legumes under irrigation gradient. I: Yield components. Agronomy Journal, 76, 549553. doi:10.2134/agronj1984.00021962007600040009x

[7] Krogman, K.K., McKenzie, R.C. and Hobbs, E.H. (1980) Response of faba bean yield, protein production and water use to irrigation. Canadian Journal of Plant Science, 60, 91-96. doi:10.4141/cjps80-013

[8] Acosta-Gallegos, J.A. and Shibata, J.K. (1989) Effect of water stress on growth and yield of indeterminate dry bean (Phaseolus vulgaris L.) cultivars. Field Crop Research, 20, 81-93. doi:10.1016/0378-4290(89)90054-3

[9] McEwen, J., Bradner, R., Briggs, G.G., Bromilow, R.H., Cockhain, A.J., Day, J.M., Fletcher, K.E., Legg, B.J., Roughely, R.J., Salt, G.A., Simpson, H.R., Webb, R.M., Witly, J.F. and Yeoman, D.P. (1981) The effects of irriga- 
tion, nitrogen fertilizer and the control of pests and pathogens on spring-sown field beans (Vicia faba L.) and residual effects on two following winter wheat crops. Journal of Agricultural Science, 96,129-150.

[10] Nadi, A.H.E. (1970) Water relations of beans (ii). Effects of differential irrigation on yield and seed size of broad beans. Experimental Agriculture, 6, 107-111. doi:10.1017/S0014479700000156

[11] Nadi, A.H.E. (1975) Water relations of beans (iii). Pod and seed yield of haricot beans under different irrigations in Sudan. Experimental Agriculture, 11, 155-158. doi:10.1017/S0014479700006608

[12] El-Nadi, A.H. (1969) Efficiency of water use by irrigated wheat in the Sudan. The Journal of Agricultural Science, 73, 261-266. doi:10.1017/S0021859600014465

[13] Dantuma, G. and Thompson, T. (1983) Whole crop physiology and yield components. In: Hebblethwaite, P.D., Ed., The Faba Bean (Vicia faba L.). A Basis for
Improvements, Butterworth, London, 143-159.

[14] Cakir, R. (2004) Effect of water stress at different development stages on vegetative and reproductive growth of corn. Field Crops Research, 89, 1-6. doi:10.1016/i.fcr.2004.01.005

[15] Khidir, M.O. and Osman, H.E. (1970) Correlation studies of some agronomic characters in sesame. Experimental Agriculture, 6, 27-31. doi:10.1016/i.fcr.2004.01.005

[16] Ahmed, I.D.Y. (2002) Effect of water stress at different growth stages on growth and productivity of faba bean (Vicia faba L.). M.Sc. Thesis, Faculty of Agriculture, University of Khartoum, Sudan.

[17] Castellanos, J.Z., Pena-Cabriales, J.J. and Acosta-Gallegos, J.A. (1996) 15N-determined dinitrogen fixation capacity of common bean (Phaseolus vulgaris L.) cultivars under water stress. Journal of Agricultural Science, 126, 327-333. doi:10.1016/j.fcr.2004.01.005 